\title{
Atorvastatin Improves Microenvironment to Enhance the Beneficial Effects of BMSCs Therapy in a Rabbit Model of Acute Myocardial Infarction
}

\author{
Zhe $\mathrm{Qu}^{\mathrm{a}} \quad$ Hongxin $\mathrm{Xu}^{\mathrm{a}} \quad$ Yihao Tian $^{\mathrm{b}} \quad$ Xuejun Jiang \\ aDepartment of Cardiology, Renmin Hospital of Wuhan University, Wuhan; bepartment of Anatomy, \\ Basic Medical College of Wuhan University, Wuhan
}

\section{Key Words}

Atorvastatin • Bone marrow stem cells (BMSCs) • Transplantation • Acute myocardial infarction

- Cardiac function - Apoptosis • Cell survival

\begin{abstract}
Background/Aims: To investigate the beneficial effects of atorvastatin added to the cell therapy with bone marrow-derived mesenchymal stromal cells (BMSCs) in a rabbit model of acute myocardial infarction (AMI). Methods: Rabbits were randomly divided into control group $(n=10)$, bone marrow stem cells transplantation group $(n=10)$, and BMSCs + atorvastatin group $(n=10)$. AMI was established by ligating the left descending coronary artery. The left ventricular (LV) function was evaluated by echocardiography. H\&E staining and Masson's Trichrome staining were performed to evaluate inflammatory cell infiltration and cardiac fibrosis. Immunohistochemistry and TUNEL were conducted to assess survival, differentiation, and apoptosis of transplanted cells and cardiomyocytes. Results: BMSCs decreased LV systolic and diastolic diameters and increased LV ejection fractions, LV fractional shortening, LV systolic pressure and LV end-diastolic pressure. Atorvastatin synergistically enhanced the BMSCsinduced improvements of ischemic cardiac dysfunction. Atorvastatin reduced inflammatory cell infiltration, cardiac fibrosis, and derangement of myocardial morphology/structure. Atorvastatin added a protective effect to cardiomyocytes against apoptotic cell death in infarct and peri-infarct areas, and also increased the survival rate of implanted BMSCs in acute myocardial ischemia. Atorvastatin also promoted cardiac differentiation of implanted BMSCs in infarct myocardium. Conclusion: Atorvastatin acts to improve the microenvironment both by synergistically enhancing the existing effects of BMSCs and by adding new therapeutic effects to BMSCs transplantation, and this combinational therapy is a superior cell/pharmacological therapeutic approach that merits future preclinical and clinical studies.
\end{abstract}




\section{Introduction}

Acute myocardial infarction (AMI) is one of the major threats to human life and health; the pandemic continues to show an upward trend as the result of changing life styles and diets worldwide, despite the ever improvements of clinical treatment over the past decades. Though immediate intervention therapy may save the lives of many AMI patients by recovering the ischemic myocardium, this comes at the price of adverse cardiac remodeling and heart failure due to, at least partially, the fact that the lost cardiomyocytes during AMI cannot be regenerated [1]. The recent advances in stem cell therapy from both basic and clinical researches have made regeneration of damaged vascular and cardiac tissues possible and demonstrated promising outcomes in the treatment of myocardial infarction [2-6]. However, in the setting of AMI, the harsh micro-environment in the infarct zone, which is filled with inflammatory response, oxidative stress, neuroendocrine activation, etc., imposes a negative impact on the survival of implanted cells and execution of their differentiation and biological functions [7-14]. Thus, the optimal efficacy of stem cell therapy in AMI has been largely hampered by the poor survival and low differentiated rates of the implanted stem cells into the myocardium.

Recent studies have demonstrated that combined therapy with mesenchymal stem cells (MSCs) and atorvastatin, a blood cholesterol-lowering agent, produces synergistic beneficial effects in the treatment of AMI, despite that neither atorvastatin nor MSCs can individually improve ventricular function significantly [15-21]. These findings retrieved the declining interest in applying and investigating stem cell therapy of AMI, and stirred up new surges for searching better strategies to boost MSCs therapy: combined MSCs therapy and pharmacotherapy is one of these proof-in-principle approaches.

In this study, we sought to investigate comprehensively the beneficial effects of atorvastatin added to the cell therapy with bone marrow-derived mesenchymal stromal cells (BMSCs) in a rabbit model of AMI. To this end, we comparatively evaluated the changes of cardiac function, cardiac repair, cardiomyocyte apoptosis, and BMSCs survival and differentiation under various conditions in non-treated control, BMSCs-transplantation, and combined BMSCs transplantation and atorvastatin.

\section{Materials and Methods}

Rabbit model of acute myocardial infarction (AMI)

Thirty Japanese white rabbits (2.0 $\pm 0.2 \mathrm{~kg}$ ) were randomly divided into 3 groups ( $\mathrm{n}=10$ for each group): control group (Control group), bone marrow stem cell transplantation group (BMSCs group), BMSCs + atorvastatin group (BMSCs/Atorvastatin group). The animals were anesthetized by intraperitoneal injection of $3 \%$ sodium pentobarbital $(40 \mathrm{mg} / \mathrm{kg}$ ). Thoracotomy was performed and the left anterior descending coronary artery was ligated. Postoperative 12-lead ECG was recorded and the successful establishment of AMI model was verified by significant ST-segment elevation. A second thoracotomy was carried out one week after AMI. The animals of BMSCs and BMSCs/atorvastatin groups were injected with BMSCs $\left(4 \times 10^{7}\right.$ cells $/ 50 \mu \mathrm{l}$ ) into the peri-infarct zone, and the control group was injected with an equal volume of serumfree culture medium. For the BMSCs/atorvastatin group, atorvastatin ( $1.5 \mathrm{mg} / \mathrm{kg} / \mathrm{day}$ ) was given through the drinking water throughout the entire experimental period starting from 3 days prior to AMI.

\section{Isolation and culturing of rabbit bone marrow stem cells (BMSCS)}

The procedures for isolation and culturing of BMSCs were essentially the same as described in detail elsewhere [22]. Briefly, two days prior to AMI, $2 \mathrm{ml}$ bone marrow was collected from femur under strictly sterile conditions, and diluted and dispersed by pipetting in phosphate buffered saline (PBS). The suspension was centrifuged at $1500 \mathrm{r} / \mathrm{min}$ at $4^{\circ} \mathrm{C}$ at room temperature (RT) for $25 \mathrm{~min}$, and the resulting pellet was resuspended in PBS containing $2 \mathrm{mM}$ EDTA, and separated in a Ficoll (1.073 g/ml) density gradient centrifugation (cell suspension:ficoll=1.5:1.0) at 500 $\times \mathrm{g}$ at RT for $30 \mathrm{~min}$. The mononuclear fraction interphase was collected, washed twice in PBS/EDTA. The final pellet was resuspended in 12 ml Dulbeccos 


\section{Cellular Physiology Cell Physiol Biochem 2013;32:380-389 \\ \begin{tabular}{l|l} 
Dol: 10.1159/000354445 & 2013 S. Karger AG, Basel
\end{tabular}

Modefied Eagle Medium (DMEM)/F12 cell culture medium $(+10 \%$ fetal calf serum, $100 \mathrm{U} / \mathrm{ml}$ penicillin, and $100 \mu \mathrm{g} / \mathrm{ml}$ streptomycine; $37^{\circ} \mathrm{C}, 5 \% \mathrm{CO}_{2}$ ) and seeded on gelatine-coated petri dishes. For the first $24 \mathrm{~h}$ cells were incubated with additional $10 \mu \mathrm{M}$ 5-azacytidine (an inhibitor of DNA methyltransferase), then continued to be cultured for 4 days. Cell culture medium was changed every $48 \mathrm{~h}$, and non-adherent hematopoetic cells were discarded.

Passaging was carried out at a confluence of $>70 \%$. The medium was removed and the cells were washed with serum-free medium. Trypsin (0.25\%) was added into the flask for digestion. Trypsin was removed when the cell axons became retracted and rounded and serum-containing medium was added to terminate the digestion. The collected cell suspension was centrifuged and the supernatant was discarded. Cells were resuspended in culture medium $2 \times 10^{5} / \mathrm{ml}$ in a $25 \mathrm{~m}^{2}$ flask and an aliquot of medium was used for cell counting.

\section{Immunocytochemistry characterization of BMSCs}

The isolated and expanded BMSCs were fixed with 4\% paraformaldehyde for $15 \mathrm{~min}$ and blocked in goat or rabbit serum for $1 \mathrm{~h}$ at $37^{\circ} \mathrm{C}$. The cells were then incubated with various primary antibodies for $24 \mathrm{~h}$ at $4^{\circ} \mathrm{C}$, followed by secondary antibodies (fluorescein isothiocyanate [FITC] or tetraethyl rhodamine isothiocyanate [TRITC] conjugated) for $1 \mathrm{~h}$ at $37^{\circ} \mathrm{C}$. The primary antibodies for BMSC biomarker proteins included goat polyclonal anti-CD34, ant-CD44, anti-CD90, anti-CD166, and anti-BDNF, all purchased from Santa Cruz Biotech (CA, USA). Finally, nuclei were counterstained with Hoechst (1:1000) for 10 min at room temperature. The cells were visualized using a fluorescence microscope (Nikon 80i, Japan). Positive percentages of cells in five nonoverlapping fields of view $(\times 200)$ of each slide were counted, and the average represented the positive rate of each marker.

\section{Transplantation of BMSCS}

Prior to transplantation, the BMSCs were labeled with DAPI (4,6-linked amidino-2-phenylindole dihydrochloride; $50 \mu \mathrm{g} / \mathrm{ml}$ ) by incubating for $2 \mathrm{~h}$ and then washed with pre-cooled PBS three times. The cells were then digested with $0.25 \%$ trypsin, suspended at $4 \times 10^{7}$ cells $/ 50 \mu \mathrm{l}$ in DMEM-F12 serum-free medium, and stored on ice until transplantation. Thoracotomy was performed to expose the heart in rabbits one week after AMI, and the prepared cells were intramuscularly injected into the peri-infarct myocardium. Intramuscular injection of penicillin (800 kunits/day) was carried out three days post surgery to prevent infection.

\section{Echocardiography}

Echocardiographic evaluation of cardiac function was conducted prior to AMI and four weeks after cell transplantation, using ACUSON Sequoia 512 Ultrasound Imaging system (USA) equipped with a cardiac probe (Model 7V3) and a $6 \mathrm{MHz}$ transducer. Rabbits were fixed on four limbs in the supine position in a non-narcotic state. Two-dimensional M-mode imaging was taken in the parasternal long and short axis views apical two-chamber and four-chamber views, and left ventricular (LV) long and short axis views. LV end-diastolic diameter (Dd) and systolic diameter (Ds) were measured in the LV long axis view; LV ejection fraction (EF) was determined in the papillary muscle level short axis view; and LV shortening fraction was automatically calculated as: $\mathrm{LVFS}=[(\mathrm{Dd}-\mathrm{Ds}) / \mathrm{Dd}] \times 100 \%$. All values were taken as the mean of triplicate measurements.

\section{Hemodynamic detection}

Four weeks after transplantation, the animals were fixed on the operation table and anesthetized by intraperitoneal injection of $3 \%$ sodium pentobarbital $(40 \mathrm{mg} / \mathrm{kg})$. The right common carotid artery was separated and cannulated with a $6 \mathrm{~F}$ soft catheter to deliver a bolus of sodium heparin (500 IU/ kg). The catheter was then advanced into LV. The catheter was connected to a 32-channel polygraph recorder through a transducer to record LV systolic pressure (LVSP), LV end-diastolic pressure (LVEDP) and other indicators of cardiac function.

\section{Specimen processing}

After measurements of cardiac function and hemodynamic parameters, chest was opened and heart was quickly excised and rinsed with cold saline. Then, the heart was cut along the short axis and chopped 


\section{Cellular Physiology Cell Physiol Biochem 2013;32:380-389 \begin{tabular}{ll|l} 
and Biochemistry & $\begin{array}{l}\text { DOI: 10.1159/000354445 } \\
\text { Published onlne: August 26, 2013 }\end{array}$ & $\begin{array}{l}\text { () 2013 S. Karger AG, Basel } \\
\text { www.karger.com/cpb }\end{array}$ \\
\cline { 2 - 3 }
\end{tabular} \\ Qu/Xu/Tian/Jiang: Atorvastatin Adds Beneficial Effects to BMSCs Transplantation}

Fig. 1. Immunocytochemical characterization of BMSCs at passage 2 stage. Immunoreactivities of BDNF and CD90 were detected by TRITC-labeled secondary antibody in red, and immunoreactivities of CD44 and CD166 were detected by FITC-labeled secondary antibody in green. Cell nuclei were counterstained with Hoechst in blue.

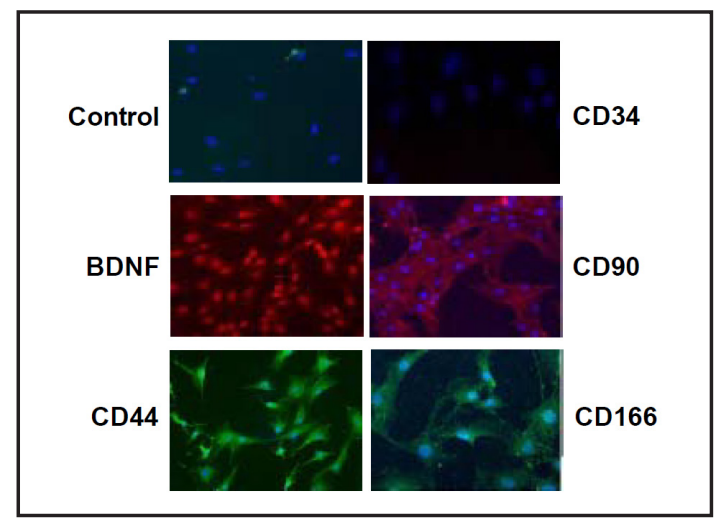

into $\sim 1-\mathrm{cm}$ chunks. The tissue blocks from infarct and border zones were separately cryo-sectioned and embedded in paraffin for later use.

Hematoxylin and eosin (H\&E) staining and Masson's Trichrome staining

The paraffin-embedded sections were stained by H\&E or by Masson's Trichrome dye. For Masson's Trichrome staining, collagen was in blue, muscle fibers in red, and nucleus in blue-black.

\section{Immunohistochemistry}

To determine the survival rate of transplanted cells and the differentiation of transplanted cells into cardiomyocytes and vascular cells, immunohistochemistry was carried out four weeks after cell transplantation. To this end, the frozen myocardial tissue preparations were cryo-cut into 5 - $\mu \mathrm{m}$ thick sections which were subject to DAPI staining to identify the transplanted BMSCs. Two sections were randomly selected from infarct and peri-infarct zones, respectively, for examination under a fluorescence microscope, and for each section, five fields were randomly selected for counting the number of cells labeled with DAPI. The survival rates of the transplanted cells were compared between BMSCs and BMSCs/Atorvastatin.

The sections were treated with primary antibodies to troponin T and VECFVIII to identify cardiac cells and vascular cells, respectively, with Cy3 (red fluorescence)-labeled antibody being used as the secondary antibody. The proportion of troponin T-positive cells (red; cardiac myocytes) to DAPI-positive cells (nuclei stained blue indicated the transplanted BMSCs) counted under a laser scanning confocal microscope was taken to indicate the differentiation rate to heart cells. Similarly, the proportion of VECFVIII-positive cells (red; vascular cells) to DAPI-positive cells was used to indicate the differentiation rate to vascular cells.

\section{TUNEL staining}

Apoptotic cells were detected from the tissue sections of the infarct and boarder zones, using TENEL staining methods. Detailed procedures were according to the manufacturer's instruction. For each section, apoptotic cells were counted from five randomly selected fields and percentage of apoptotic cells over the total number of cells counted was taken as the apoptosis index (AI).

\section{Statistical analysis}

Data are presented as mea \pm SD. The group comparisons were performed by using ANOVA and $q$ test. The intra-group differences of cell differentiation in animals subject to BMSCs transplantation were analyzed using the chi-square test. Two-tailed $P<0.05$ was considered statistically significant. All statistical analyses were performed using SPSS13.0 software.

\section{Results}

Characterization of BMSCs

Immunocytochemical staining indicated that nearly all cells were positive for BDNF (99.7\%) and CD44 (99.2\%), and most cells expressed CD166 (97.3\%) and CD90 (96.5\%) 
Table 1. Comparisons of cardiac function measured by echocardiography and hemodynamic examination in a rabbit model of acute myocardial infarction (mean \pm SD)

\begin{tabular}{lcccccc}
\hline Group (AMI) & Dd $(\mathrm{cm})$ & Ds $(\mathrm{cm})$ & LVFS $(\%)$ & $\begin{array}{c}\text { LVEF } \\
(\%)\end{array}$ & LVSP & LVEDP \\
\hline Control & $1.39 \pm 0.17$ & $1.05 \pm 0.12$ & $24.57 \pm 1.43$ & 48.67 & $97.3 \pm 7.4$ & $-7.8 \pm 1.1$ \\
BMSCs & $1.26 \pm 0.11^{*}$ & $0.92 \pm 0.09^{*}$ & $27.41 \pm 1.47^{*}$ & $59.14^{*}$ & $106.8 \pm 9.1^{*}$ & $-10.2 \pm 1.1^{*}$ \\
BMSCs/Atorvastatin & $1.15 \pm 0.08^{*} \#$ & $0.81 \pm 0.07^{*} \#$ & $29.52 \pm 1.51^{*} \#$ & $67.32^{*}$ & $113.4 \pm 11.7^{*} \#$ & $-12.4 \pm 1.2^{*} \#$ \\
\hline
\end{tabular}

AMI: acute myocardial infarction; BMSCs: rabbit bone marrow stem cells; Dd: left ventricular end-diastolic diameter; Ds: left ventricular systolic diameter; LVFS: left ventricular fractional shortening; LVEF: left ventricular ejection fraction; LVSP: left ventricular systolic pressure; LVEDP: left ventricular end-diastolic pressure; ${ }^{*} \mathrm{P}<0.05$ vs Control; $\# \mathrm{P}<0.05$ vs BMSCs.

Fig. 2. Reduction of cardiac fibrosis and inflammatory cell infiltration by atorvastatin in rabbit hearts. (A) Representative images of H\&E staining and Masson's Trichrome staining (200x magnification) of sections from infarct and peri-infarct zones of a rabbit heart subject to acute myocardial infarction, showing the effects of BMSCs transplantation and combined atorvastatin and BMSCs on the inflammatory cell infiltration, cardiac fibrosis (blue), viable cardiomyocytes, and derangement of cardiac fibres. (B)

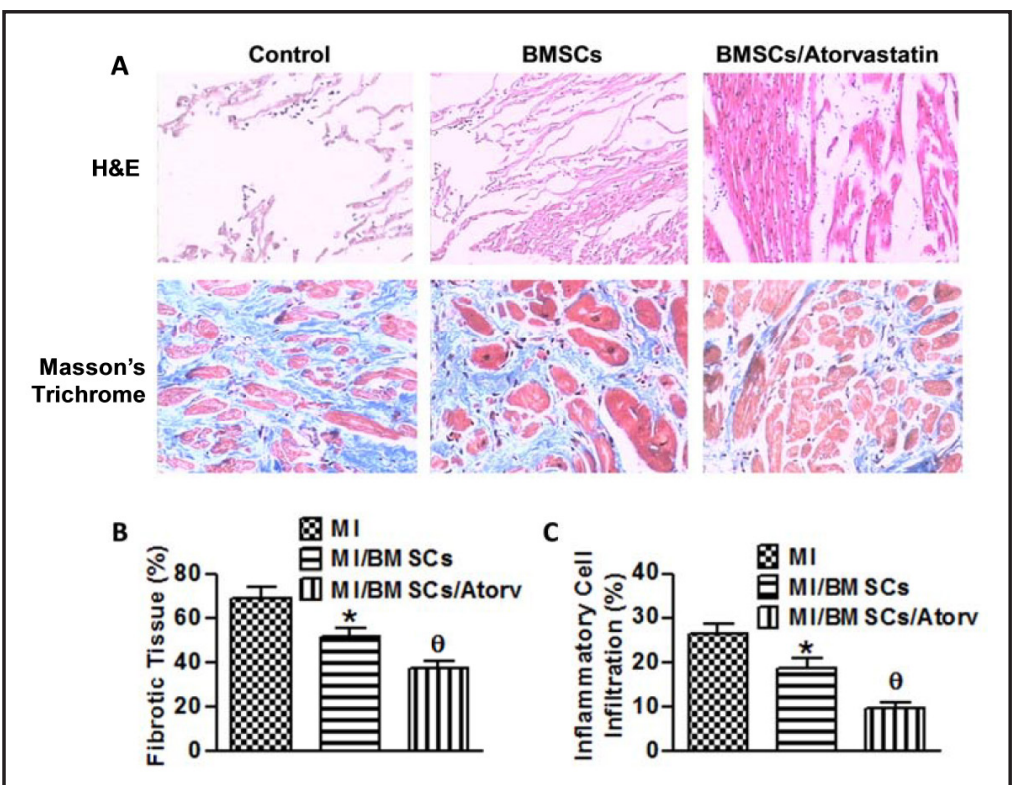

Mean data on the percent fibrotic tissues under varying conditions. The values were obtained from randomly selected 10 fields for each rabbit. Atorv: atorvastatin $(1.5 \mathrm{mg} / \mathrm{kg} /$ day $) .{ }^{*} \mathrm{P}<0.05$ vs. MI; ${ }^{\theta} \mathrm{P}<0.05$ vs. BMSCs; $n=5$ animals for each group. (C) Mean data on the percentage of inflammatory cell infiltration under varying conditions. The values were obtained from randomly selected 10 fields for each rabbit. *P<0.05 vs. $\mathrm{MI} ;{ }^{\theta} \mathrm{P}<0.05$ vs. BMSCs alone; $\mathrm{n}=5$ animals for each group.

(Fig. 1). All cells were negative for CD34. These data are in line with the characteristics of BMSCs $[23,24]$.

\section{Atorvastatin enhances BMSCs-induced improvement of ischemic cardiac dysfunction}

Four animals died during the course of the study period, with two in control group, one in the BMSCs group, and one in the BMSCs/Atorvastatin group. The causes of death were ventricular fibrillation and acute left ventricular failure.

BMSC transplantation significantly alleviated the AMI-induced enlargement of left ventricular end-diastolic diameter (Dd) and left ventricular systolic diameter (Ds; Table 1). On the contrary, BMSCs restored the diminished LVFS, LVEF, LVSP, and LVEDP in AMI. All these beneficial effects of BMSCs were markedly enhanced by atorvastatin treatment (Table 1).

Atorvastatin enhances BMSCs-induced repair of ischemic myocardial impairment

As depicted in Figure 2, H\&E staining and Masson's Trichrome staining demonstrated profound inflammatory cell infiltration, severe cardiac fibrosis, sparse viable cardiomyocytes, and patchy distribution of lesions in the infarcted area in untreated control group. BMSCs 
Fig. 3. Cytoprotection against cardiomyocyte apoptosis by atorvastatin in rabbit hearts. (A) Typical examples of TUNEL staining of defragmentated nuclei (brown; 200× magnification) showing the effects BMSCs transplantation and combined atorvastatin and BMSCs on apoptotic cells of cardiomyocytes in infract and peri-infarct areas of a rabbit heart of acute myocardial infarction. (B) Mean data of \% TUNEL positive cells. Note that atorvastatin reduced the number of cardiomyocyte apoptosis/TUNEL positive cells in acute myocardial ischemia. ${ }^{\theta} \mathrm{P}<0.05$ vs. BMSCs alone; $\mathrm{n}=5$ for each group.

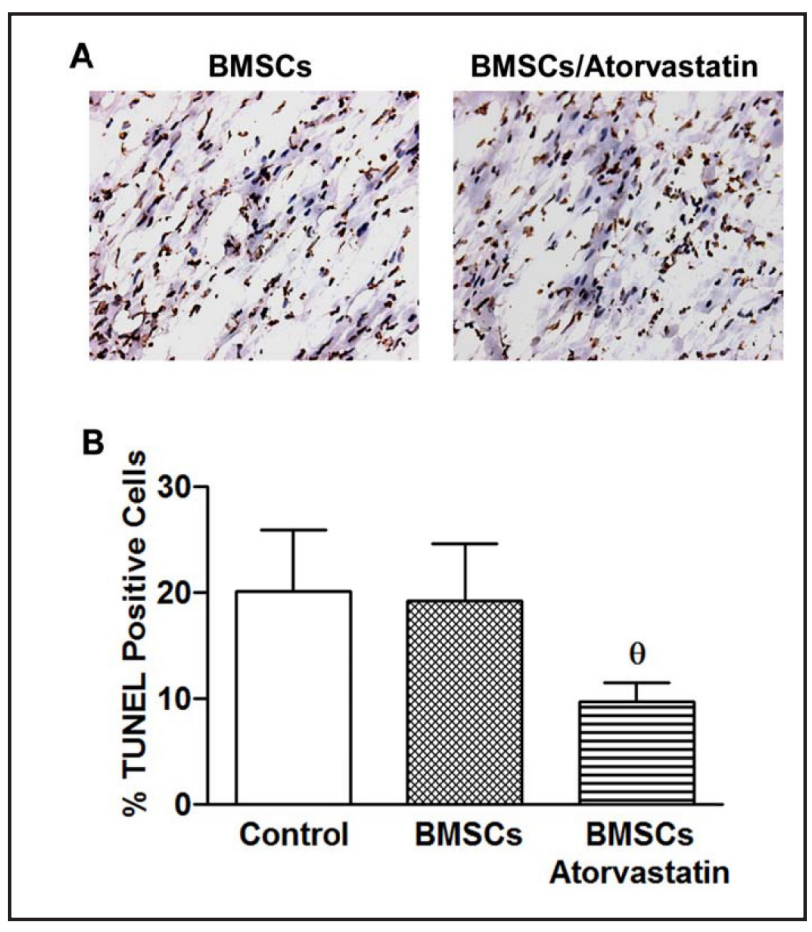

transplantation diminished fibrosis and inflammatory cell infiltration, and increased viable cardiac cells. Atorvastatin treatment produced synergetic effects with BMSCs transplantation in extenuating the structural impairment, inflammatory response and cell death. For example, the percent fibrotic tissue was $68.7 \pm 5.3 \%$ in MI, $51.6 \pm 3.8 \%$ in the BMSCs group, and $37.3 \pm 3.1 \%$ in the BMSCs/Atorvastatin group $(P<0.05$; F-test and $P<0.05$ between the BMSCs/Atorvastatin and BMSCs groups) (Fig. 2B). The percentage of inflammatory cell infiltration was $26.5 \pm 2.3 \%$ in the MI group, $18.6 \pm 2.2 \%$ in the BMSCs group, and $9.5 \pm 1.3 \%$ in the BMSCs/Atorvastatin group $(P<0.05$; F-test and $P<0.05$ between the BMSCs/Atorvastatin and BMSCs groups) (Fig. 2C).

\section{Atorvastatin diminishes cardiomyocyte apoptosis in acute myocardial ischemia}

TUNEL staining revealed that BMSCs transplantation alone did not significantly alter apoptotic cell death of cardiomyocytes in infarcted and peri-infarct areas (Fig. 3), as indicated by the nearly identical AI values in the BMSCs group $(19.2 \pm 5.4 \% ; P>0.05)$ and the Control group $(20.1 \pm 5.8 \%)$. Combinational therapy with atorvastatin administration and BMSCs transplantation, however, significantly reduced AI to $9.7 \pm 1.8 \%$, a $\sim 50 \%$ reduction of apoptotic cells.

Atorvastatin enhances survival of implanted BMSCs in acute myocardial ischemia

Atorvastatin significantly preserved the survival of BMSCs in the infracted area, as determined by the counts of DAPI-positive cells under a fluorescence microscope (358.7 \pm 88.3 /high power field (HPF) for BMSCs/atorvastatin vs. 76.8 $\pm 20.9 /$ HPF for BMSCs alone; $P<0.01$; Fig. 4).

Atorvastatin promotes cardiac differentiation of implanted BMSCs in infarct myocardium

Our results from immunohistochemistry experiments showed that some of the transplanted cells of the BMSCs group and BMSCs/Atorvastatin group expressed troponin $\mathrm{T}$ and VECFVIII (Fig. 4). The proportion of the troponin T-expressing transplanted cells after combination therapy with BMSCs and atorvastatin was significantly higher than that of BMSCs alone, indicating a higher rate of myocardial cell differentiation of transplanted cells in the presence of atorvastatin. 
Fig. 4. Immunohistochemical assessment of implanted BMSCs (blue fluorescence; 200× magnification) (A \& B), and differentiation to cardiac cells with troponin T staining (cTnT; red) (C), or to vascular cells with VECF VIII staining (vascular endothelial cell factor VIII; red) (D). Note that atorvastatin promoted the survival and myocardial differentiation of BMSCs, as indicated by the larger numbers of blue staining for BMSCs and red staining for cardiac cells, compared with BMSCs transplantation alone. $* \mathrm{P}<0.05$ vs. MI; ${ }^{\theta} \mathrm{P}<0.05$ vs. BMSCs alone; ${ }^{\xi} \mathrm{P}<0.001$ vs. BMSCs alone; $\mathrm{n}=5$ animals for each group.

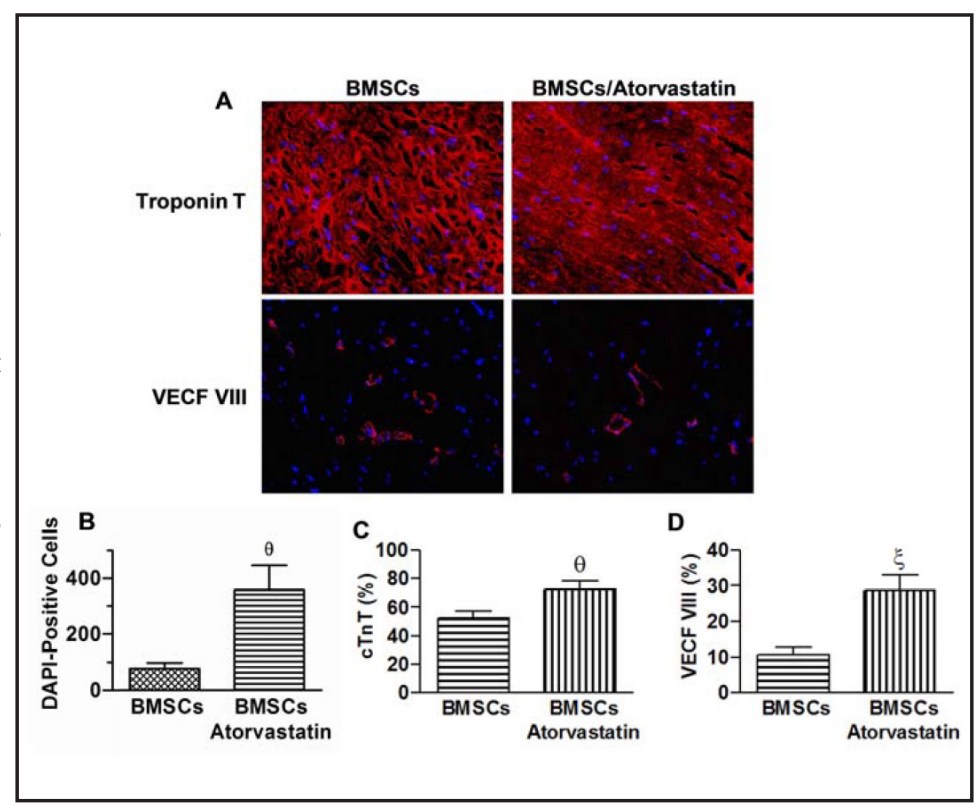

\section{Discussion}

Our data in this study revealed that atorvastatin offered significant beneficial effects on transplanted BMSCs and myocardium in the setting of AMI, as manifested by the following improvements. (1) Atorvastatin enhanced BMSCs-induced improvement of ischemic cardiac dysfunction, as reflected by the magnified restoration of the enlarged Ds and Dd, and the decreased LVFS, LVEF, LVSP, and LVEDP in AMI. (2) Atorvastatin enhanced BMSCs-induced cardiac repair of ischemic myocardial impairment, as indicated by the synergetic effects against inflammatory cell infiltration, cardiac fibrosis, and derangement of myocardial morphology/structure. (3) Atorvastatin added a protective effect to cardiomyocytes against apoptotic cell death in infarct and peri-infarct areas, an antiapoptotic property otherwise absent with BMSCs transplantation alone. (4) Atorvastatin enhanced the survival rate of implanted BMSCs in acute myocardial ischemia. And (5) atorvastatin promotes cardiac differentiation of implanted BMSCs in infarct myocardium. All these effects point to the ability of atorvastatin to improve the microenvironment so as to preserve implanted BMSCs and improve cardiomyocytes leading to amelioration of cardiac function and myocardial repair in AMI. Clearly, atorvastatin acts both by synergistically enhancing the existing effects of BMSCs and by adding new therapeutic components to BMSCs transplantation, and this combinational therapy is a superior cell/pharmacological therapeutic approach that merits future preclinical and clinical studies.

Although most of the animals and clinical trials have confirmed stem cell transplantation is safe for the treatment of cardiac disease, but the therapeutic efficacy has been found insignificant [8-14]. Studies have shown that stem cells transplanted into damaged tissue die because of apoptosis and perhaps other forms of cell death as well, mostly in a week after transplantation [25-27]. No more than $15 \%$ of the transplanted cells can survive for up to 12 weeks [21], which seriously restricted the potential of stem cells to repair damaged myocardium. Therefore, how to maximize the potential of stem cell transplantation in the treatment of AMI has become an urgent task for researchers and clinicians.

The causes for the substantial death of transplanted stem cells in the infarcted myocardium are likely multiple and intricate, but are not yet fully understood. Existing evidence suggests that ischemia and hypoxia, inflammation, apoptosis, oxidative stress, and neuroendocrine activation together create a grim and adverse microenvironment in the infracted myocardium to threaten the survival of implanted stem cells [8-27]. Clearly, 


\section{Cellular Physiology Cell Physiol Biochem 2013;32:380-389 \\ \begin{tabular}{c|c|c|}
\hline DOI: 10.1159/000354445 26,2013 & O 2013 S. Karger AG, Basel \\
\hline
\end{tabular}

maximizing the survival rate of transplanted cells is a critical step towards maximizing the potential of stem cell therapy for AMI. At present, there are two major strategies for promoting the survival rate of transplanted cells. The first approach is to boost up the ability of stem cells to tolerate ischemic insults by preconditioning or priming the cells prior to transplantation $[28,29]$, or by permanent or transient genetic engineering of stem cells to overexpress anti-inflammatory and anti-apoptotic genes [30,31]. And the second approach is to improve the microenvironment by minimizing the harmful factors secreted into and around the area where stem cells are implanted, normally the infarct and peri-infarct zones, so as to relieve the insults to the implanted cells [32-39]. In this second scenario, implanted stem cells have better chance to survive and differentiate, so as to better execute their biological functions. By comparison, the first approach with genetic modification has the potential to bring about certain unwanted effects due to overexpression of foreign genes, which may limit its clinical applications. Thus, improving microenvironment for stem cell transplantation may be safer and more feasible.

Statins are one of the most commonly used agents in patients with coronary heart disease owing to their superior ability to reduce blood cholesterols [40]. Recent studies revealed that these agents exert a wide spectrum of cellular functions in addition to their lipid-lowering action, including anti-inflammatory, anti-apoptotic, anti-fibrotic, angiogenesis-promoting, and plaque-stabilizing effects [41-43]. These properties are well predicted to offer improvement of the microenvironment for implanted stem cells. The experimental results in the present study indeed provided several lines of evidence in support of this notion. Compared with BMSCs transplantation alone, the combined treatment with atorvastatin and BMSCs afforded synergistically beneficial effects on ischemic myocardial injury by AMI to retard the adverse ventricular remodeling and improve cardiac function.

\section{Acknowledgement}

This project was supported in part by grants from the national Natural Science Foundation of China (No. 30700314) and Wuhan Science and Technology Bureau of Hubei province, China (No. 20065004116-02), granted to Dr. Xu.

\section{References}

1 Przybyt E, Harmsen MC: Mesenchymal Stem Cells: promising for myocardial regeneration? Curr Stem Cell Res Ther 2013;270-277.

-2 Williams AR, Suncion VY, McCall F, Guerra D, Mather J, Zambrano JP, Heldman AW, Hare JM: Durable scar size reduction due to allogeneic mesenchymal stem cell therapy regulates whole-chamber remodeling. J Am Heart Assoc 2013;2:e000140.

3 Richardson JD, Bertaso AG, Psaltis PJ, Frost L, Carbone A, Paton S, Nelson AJ, Wong DT, Worthley MI, Gronthos S, Zannettino AC, Worthley SG: Impact of timing and dose of mesenchymal stromal cell therapy in a preclinical model of acute myocardial infarction. J Card Fail 2013;19:342-353.

-4 Lu M, Zhao S, Liu Q, Jiang S, Song P, Qian H, Zhang Y, Ling J, Yan C, Cheng H, Ma N, Zhao H, Liu Y: Transplantation with autologous mesenchymal stem cells after acute myocardial infarction evaluated by magnetic resonance imaging: an experimental study. J Thorac Imaging 2012;27:125-35.

5 Orlic D, Kajstura J, Chimenti S, Bodine DM, Leri A, Anversa P: Bone marrow stem cells regenerate infarcted myocardium. Pediatr Transplant 2003;7:S86-88.

6 Donndorf P, Strauer BE, Haverich A, Steinhoff G: Stem cell therapy for the treatment of acute myocardial infarction and chronic ischemic heart disease. Curr Pharm Biotechnol 2013;14:12-19.

7 Song H, Kwon K, Lim S, Kang SM, Ko YG, Xu Z, Chung JH, Kim BS, Lee H, Joung B, Park S, Choi D, Jang Y, Chung NS, Yoo KJ, Hwang KC: Transfection of mesenchymal stem cells with the FGF-2 gene improves their survival under hypoxic conditions. Mol Cells 2005;19:402-407. 


\section{Cellular Physiology Cell Physiol Biochem 2013;32:380-389 \begin{tabular}{l|l|l} 
DOI: 10.1159/000354445 & O 2013 S. Karger AG, Basel \\
and & ww.karger.com/cpb
\end{tabular}

8 Samper E, Diez-Juan A, Montero JA, Sepúlveda P: Cardiac cell therapy: boosting mesenchymal stem cells effects. Stem Cell Rev 2013;9:266-280.

-9 Koudstaal S, Jansen Of Lorkeers SJ, Gaetani R, Gho JM, van Slochteren FJ, Sluijter JP, Doevendans PA, Ellison GM, Chamuleau SA. Concise review: Heart regeneration and the role of cardiac stem cells. Stem Cells Transl Med 2013; 2013;2:434-443.

10 Hsiao LC, Carr C, Chang KC, Lin SZ, Clarke K. Review Article: Stem Cell-based Therapy for Ischemic Heart Disease. Cell Transplant 2013;22:663-675.

11 Haider KH, Ashraf M: Preconditioning approach in stem cell therapy for the treatment of infarcted heart. Prog Mol Biol Transl Sci 2012;111:323-356.

-12 Clifford DM, Fisher SA, Brunskill SJ, Doree C, Mathur A, Watt S, Martin-Rendon E: Stem cell treatment for acute myocardial infarction. Cochrane Database Syst Rev 2012;2:CD006536. doi: 10.1002/14651858. CD006536.pub3.

13 Dauwe DF, Janssens SP: Stem cell therapy for the treatment of myocardial infarction. Curr Pharm Des 2011;17:3328-3340.

14 Dai W, Kloner RA: Bone marrow-derived cell transplantation therapy for myocardial infarction: lessons learned and future questions. Am J Transplant 2011;11:2297-2301.

15 Yang YJ, Qian HY, Huang J, Geng YJ, Gao RL, Dou KF, Yang GS, Li JJ, Shen R, He ZX, Lu MJ, Zhao SH: Atorvastatin treatment improves survival and effects of implanted mesenchymal stem cells in post-infarct swine hearts. Eur Heart J 2008;29:1578-1590.

16 Cai A, Zheng D, Dong Y, Qiu R, Huang Y, Song Y, Jiang Z, Rao S, Liao X, Kuang J, Dai G, Mai W: Efficacy of Atorvastatin combined with adipose-derived mesenchymal stem cell transplantation on cardiac function in rats with acute myocardial infarction. Acta Biochim Biophys Sin (Shanghai) 2011;43:857-866.

17 Wang A, Shen F, Liang Y, Wang J: Marrow-derived MSCs and atorvastatin improve cardiac function in rat model of AMI. Int J Cardiol 2011;150:28-32.

18 Dong Q Yang Y, Song L, Qian H, Xu Z: Atorvastatin prevents mesenchymal stem cells from hypoxia and serum-free injury through activating AMP-activated protein kinase. Int J Cardiol 2011;153:311-316.

19 Post S, Post MC, van den Branden BJ, Eefting FD, Goumans MJ, Stella PR, van Es HW, Wildbergh TX, Rensing BJ, Doevendans PA: Early statin treatment prior to primary PCI for acute myocardial infarction: REPERATOR, a randomized placebo-controlled pilot trial. Catheter Cardiovasc Interv 2012;80:756-765.

20 Jazi SM, Esfahani MH, Fesharaki M, Moulavi F, Gharipour M: Initial clinical outcomes of intracoronary infusion of autologous progenitor cells in patients with acute myocardial infarction. ARYA Atheroscler 2012;7:162-167.

21 Zhang M, Methot D, Poppa V, Fujio Y, Walsh K, Murry CE: Cardiomyocyte grafting for cardiac repair: graft cell death and antideath strategies. J Mol Cell Cardiol 2001;33:907-921.

22 Dhein S, Garbade J, Rouabah D, Abraham G, Ungemach FR, Schneider K, Ullmann C, Aupperle H, Gummert JF, Mohr FW: Effects of autologous bone marrow stem cell transplantation on beta-adrenoceptor density and electrical activation pattern in a rabbit model of non-ischemic heart failure. J Cardiothorac Surg 2006;1:17.

23 Ning J, Li C, Li H, Chang J: Bone marrow mesenchymal stem cells differentiate into urothelial cells and the implications for reconstructing urinary bladder mucosa. Cytotechnology 2011;63:531-539.

24 Honczarenko M, Le Y, Swierkowski M, Ghiran I, Glodek AM, Silberstein LE: Human bone marrow stromal cells express a distinct set of biologically functional chemokine receptors. Stem Cells 2006;24:1030-1041.

25 Flynn A, Chen X, O'Connell E, O'Brien T: A comparison of the efficacy of transplantation of bone marrowderived mesenchymal stem cells and unrestricted somatic stem cells on outcome after acute myocardial infarction. Stem Cell Res Ther 2012;3:36.

26 Yao Y, Zhang F, Wang L, Zhang G, Wang Z, Chen J, Gao X: Lipopolysaccharide preconditioning enhances the efficacy of mesenchymal stem cells transplantation in a rat model of acute myocardial infarction. J Biomed Sci 2009;16:74. doi: 10.1186/1423-0127-16-74.

27 Abbate A, Biondi-Zoccai GG, Van Tassell BW, Baldi A: Cellular preservation therapy in acute myocardial infarction. Am J Physiol Heart Circ Physiol 2009;296:H563-565.

-28 Carvalho JL, Braga VB, Melo MB, Campos AC, Oliveira MS, Gomes DA, Ferreira AJ, Santos RA, Goes AM: Priming mesenchymal stem cells boosts stem cell therapy to treat myocardial infarction. J Cell Mol Med 2013;17:617-625. 


\section{Cellular Physiology Cell Physiol Biochem 2013;32:380-389

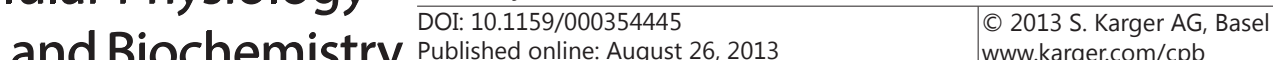

-29 Herrmann JL, Abarbanell AM, Wang Y, Weil BR, Poynter JA, Manukyan MC, Meldrum DR: Transforming growth factor- $\alpha$ enhances stem cell-mediated postischemic myocardial protection. Ann Thorac Surg 2011;92:1719-1725.

30 Wang L, Pasha Z, Wang S, Li N, Feng Y, Lu G, Millard RW, Ashraf M: Protein kinase G1 $\alpha$ overexpression increases stem cell survival and cardiac function after myocardial infarction. PLoS One 2013;8:e60087.

-31 Huang F, Zhu X, Hu XQ, Fang ZF, Tang L, Lu XL, Zhou SH: Mesenchymal stem cells modified with miR-126 release angiogenic factors and activate Notch ligand Delta-like-4, enhancing ischemic angiogenesis and cell survival. Int J Mol Med 2013;21:484-492.

-32 Miettinen JA, Salonen RJ, Ylitalo K, Niemelä M, Kervinen K, Säily M, Koistinen P, Savolainen ER, Mäkikallio TH, Huikuri HV, Lehenkari P: The effect of bone marrow microenvironment on the functional properties of the therapeutic bone marrow-derived cells in patients with acute myocardial infarction. J Transl Med 2012;10:66. doi: 10.1186/1479-5876-10-66.

33 Gao M, Yang J, Liu G, Wei R, Zhang L, Wang H, Wang G, Gao H, Chen G, Hong T: Ghrelin promotes the differentiation of human embryonic stem cells in infarcted cardiac microenvironment. Peptides 2012;34:373-379.

34 Li TS, Cheng K, Lee ST, Matsushita S, Davis D, Malliaras K, Zhang Y, Matsushita N, Smith RR, Marbán E: Cardiospheres recapitulate a niche-like microenvironment rich in stemness and cell-matrix interactions, rationalizing their enhanced functional potency for myocardial repair. Stem Cells 2010;28:2088-2098.

-35 Rameshwar P: Microenvironment at tissue injury, a key focus for efficient stem cell therapy: A discussion of mesenchymal stem cells. World J Stem Cells 2009;1:3-7.

-36 Alestalo K, Lehtonen S, Yannopoulos F, Mäkelä T, Mäkelä J, Ylitalo K, Väisänen T, Juvonen T, Anttila V, Sequeiros RB, Lappi-Blanco E, Lehenkari P: Activity of mesenchymal stem cells in a nonperfused cardiac explant model. Tissue Eng Part A 2013;19:1122-1131.

-37 Massollo M, Podestà M, Marini C, Morbelli S, Cassanelli C, Pinto V, Ubezio G, Curti G, Uccelli A, Frassoni F, Sambuceti G: Contact with the bone marrow microenvironment readdresses the fate of transplanted hematopoietic stem cells. Exp Hematol 2010;38:968-977.

38 Chen YR, Li Y, Chen L, Yang XC, Su PX, Cai J: The infarcted cardiac microenvironment cannot selectively promote embryonic stem cell differentiation into cardiomyocytes. Cardiovasc Pathol 2011;20:77-83.

-39 Rameshwar P, Qiu H, Vatner SF: Stem cells in cardiac repair in an inflammatory microenvironment. Minerva Cardioangiol 2010;58:127-46.3

40 Weng TC, Yang YH, Lin SJ, Tai SH: A systematic review and meta-analysis on the therapeutic equivalence of statins. J Clin Pharm Ther 2010;35:139-151.

41 McKenney JM: Combination treatment with atorvastatin plus niacin provides effective control of complex dyslipidemias: a literature review. Postgrad Med 2012;124:7-20.

42 Lipinski MJ, Cauthen CA, Biondi-Zoccai GG, Abbate A, Vrtovec B, Khan BV, Vetrovec GW: Meta-analysis of randomized controlled trials of statins versus placebo in patients with heart failure. Am J Cardiol 2009;104:1708-1716.

43 Horwich TB, MacLellan WR: Atorvastatin and statins in the treatment of heart failure. Expert Opin Pharmacother 2007;8:3061-3068. 